\title{
Development of an antimicrobial urinary catheter to inhibit urinary catheter encrustation
}

\author{
Rachael P. C. Jordan ${ }^{1 *}$, Sladjana Malic ${ }^{1,2}$, Mark G. Waters ${ }^{1,3}$, David J. Stickler ${ }^{4}$ and David W. Williams ${ }^{1}$ \\ *Correspondence: JordanRP@cardiff.ac.uk

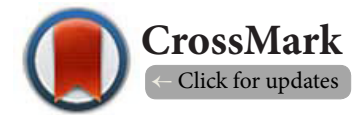 \\ 'School of Dentistry, College of Biomedical and Life Sciences, Cardiff University, Heath Park, Cardiff, CF14 4XY, Wales, UK. \\ ${ }^{2} \mathrm{~S} c h o o l$ of Healthcare Science, Manchester Metropolitan University, Manchester, M1 5GD, UK. \\ ${ }^{3} \mathrm{MBI}$ (WALES) Ltd./Technovent Ltd., Unit 5, Kingsway Buildings, Bridgend Industrial Estate, Bridgend CF31 3 YH, Wales, UK. \\ ${ }^{4}$ School of Biosciences, Main Building, Cardiff University, Museum Avenue, Cardiff CF10 3TL, Wales, UK.
}

\begin{abstract}
Background: Encrustation of urinary catheters is a frequent problem in patients with long-term indwelling catheters colonised with urease-positive bacteria such as Proteus mirabilis. Catheter blockage may follow catheter encrustation, potentially leading to systemic infection. Prevention of encrustation is difficult and avoidance of recurrence often unsuccessful. One possible preventative strategy is to use a catheter with an antimicrobial surface and development and assessment of such a surface was the aim of this research.

Methods: Initial experiments assessed the antimicrobial activity of silicone impregnated with plant-derived antimicrobials and triclosan using agar diffusion. The longevity of activity of each antimicrobial silicone was examined over a period of 11 weeks following soaking individual pieces of antimicrobial silicone in an artificial urine solution before using agar diffusion to test remaining antimicrobial activity. Live/Dead staining of bacteria colonising the surface of each antimicrobial silicone was employed to determine the bactericidal properties of each antimicrobial silicone. Selected antimicrobial silicones were subsequently evaluated for their ability to prevent catheter encrustation in an in vitro bladder model.
\end{abstract}

Results: Results showed that antimicrobial activity was obtained using $1 \%$ triclosan-impregnated silicone and that this antimicrobial activity was long-lasting (up to 11 weeks). Use of a dip coat silicone formulation, containing $0.2 \%$ triclosan, proved effective at delaying catheter encrustation with $P$. mirabilis metabolites in vitro. In 8 out of 13 independent experiments using dip-coated catheters, no catheter blockage occurred over 7 days, whilst all control catheters blocked during this period. Only on one occasion was delayed encrustation not evident with the treated catheters.

Conclusions: In summary, a dip-coat silicone containing triclosan proved effective in preventing in vitro catheter encrustation caused by P. mirabilis infection. Further studies with triclosan silicone dip coat formulation are warranted, including those that investigate potential host cell toxicity and long-term benefits following its application to indwelling urinary catheters in clinical settings.

Keywords: Proteus mirabilis, catheter associated urinary tract infection, triclosan, eugenol, terpinen-4-ol

\section{Introduction}

Catheter associated-urinary tract infections (CA-UTIs) are the most frequently encountered hospital acquired infections, with $70-80 \%$ involving an indwelling urinary catheter [1]. The widely used Foley catheter predisposes patients to CA-UTIs as it disrupts the normal protective effect of urinary flow and provides a conduit for pathogens to the bladder that 'by-passes' the natural antimicrobial mechanisms of the urethral mucosa.
Once the bladder is colonised, the inflated catheter retention balloon ensures that the bladder does not completely empty, resulting in the retention of contaminated urine in the bladder [2].

Potential consequences of CA-UTI are numerous, and include pyelonephritis, septicaemia, bladder stone development, bacteraemia, endotoxic shock, and catheter encrustation [3]. Several microbial species, including Escherichia coli and 
Jordan et al. Microbiology Discovery 2015,

http://www.hoajonline.com/journals/pdf/2052-6180-3-1.pdf

doi: $10.7243 / 2052-6180-3-1$

Pseudomonas aeruginosa can cause CA-UTIs, although it is infection by urease producing bacteria and particularly Proteus mirabilis that are frequently most problematic [4]. Proteus mirabilis produces a potent urease that hydrolyses urea leading to formation of ammonium and carbonate ions, which increase urinary $\mathrm{pH}$. In alkaline urine, magnesium and calcium phosphates precipitate and impede urinary flow through the catheter [5]. Management of urinary catheter encrustation in long-term indwelling catheters is difficult, and no single effective prevention strategy is currently recognised [6].

The emergence and spread of antibiotic resistant microorganisms had driven the need to find new antimicrobial agents and in recent years, this has led to considerable interest in the use of natural antimicrobials, which, by often targeting multiple microbial sites, are associated with reduced incidence of resistance [7]. Recently we have identified several plantderived antimicrobial agents with activity against $P$. mirabilis [8]. These studies highlighted the antimicrobial effects of eugenol (an essential oil extracted from clove oil), terpinen-4-ol and cineole (components of tea tree oil) against $P$. mirabilis. Triclosan (2,4,4'-trichloro-2'-hydroxydiphenyl ether), whilst not a natural antimicrobial agent, has been used as a biocide in numerous industrial and household products [9] and importantly, this agent is also highly effective against $P$. mirabilis [10] and as such triclosan was also evaluated in this investigation.

The aim of this present study was to use the natural antimicrobials, eugenol and terpinen-4-ol, in addition to triclosan, to develop novel antimicrobial silicone formulations that could prevent catheter encrustation. Constructed antimicrobial silicones were applied as a material insert or a 'dip coat' to Foley catheters and assessed for their ability to delay or prevent in vitro catheter encrustation following $P$. mirabilis infection. This study found that a dip coat silicone containing $0.2 \%$ triclosan was effective at preventing catheter encrustation in all but one test catheter and as such, further investigation, including host cell toxicity and effectiveness in a clinical setting is warranted.

\section{Materials and methods}

\section{Bacterial strains and culture conditions}

Bacterial isolates associated with urinary tract infection (Table 1) were cultured on Cysteine Lactose Electrolyte Deficient (CLED; Oxoid, Basingstoke, United Kingdom) agar at $37^{\circ} \mathrm{C}$. Artificial urine was used as a liquid culture medium, as previously described with incorporation of Tryptone Soya Broth (TSB) at $1 \mathrm{~g} / \mathrm{L}[\mathbf{2 0 , 2 1}$. Mueller-Hinton Broth (MHB; Oxoid) and IsoSensitest Agar (ISO; Oxoid) were used for antimicrobial assessment by zone of inhibition testing.

\section{Manufacture of antimicrobial silicone material}

Stock antimicrobial solutions were 10\% (w/w) triclosan (SigmaAldrich, Poole, United Kingdom) in 2-propanol (Sigma-Aldrich), $10 \%(\mathrm{w} / \mathrm{w})$ eugenol (Sigma-Aldrich) and 5\% (w/w) terpinen4-ol (Sigma-Aldrich), both in acetone. Solvent only controls
Table 1. Bacterial species and strains used in this study.

\begin{tabular}{|c|c|c|}
\hline Isolate & $\begin{array}{l}\text { Original source of } \\
\text { isolate }\end{array}$ & Reference \\
\hline $\begin{array}{l}\text { Proteus mirabilis NCTC } \\
11938^{*}\end{array}$ & Putrefied meat & {$[11]$} \\
\hline P. mirabilis $\mathrm{B} 2$ & Catheter biofilm & {$[12]$} \\
\hline P. mirabilis RB6 & Catheter biofilm & {$[13]$} \\
\hline P. mirabilis NSM6 & $\begin{array}{l}\text { Clinical isolate of an } \\
\text { encrusted catheter of a } \\
\text { patient undergoing long } \\
\text { term catheterisation }\end{array}$ & {$[14]$} \\
\hline $\begin{array}{l}\text { P. mirabilis } \text { NCTC }^{\circledR} \text { TM } \\
\text { ATCC }^{\circledR} 14153\end{array}$ & Reference strain & $\mathrm{n} / \mathrm{a}$ \\
\hline $\begin{array}{l}\text { P. mirabilis HI } 4320 \text {-wild } \\
\text { type }\end{array}$ & $\begin{array}{l}\text { Urine of a long-term- } \\
\text { catheterised elderly } \\
\text { patient with significant } \\
\text { bacteriuria }\end{array}$ & {$[15,16]$} \\
\hline P. mirabilis NP6 & $\begin{array}{l}\text { Urine of a patient at a } \\
\text { nursing home }\end{array}$ & {$[17]$} \\
\hline P. mirabilis RB22 & Clinical isolate & $\mathrm{n} / \mathrm{a}$ \\
\hline P. mirabilis urease neg 2 & Clinical isolate & $\mathrm{n} / \mathrm{a}$ \\
\hline Proteus vulgaris $\mathrm{H} 2 \mathrm{~V}$ & Clinical isolate & $\mathrm{n} / \mathrm{a}$ \\
\hline P. vulgaris NSM19 & Clinical isolate & {$[18]$} \\
\hline P. vulgaris SDM2 & Catheter biofilm & {$[13]$} \\
\hline Providencia rettgeri SDM1 & Catheter biofilm & {$[13]$} \\
\hline Providencia stuartii NSM40 & $\begin{array}{l}\text { Indwelling catheter of } \\
\text { long term catheterised } \\
\text { patient }\end{array}$ & {$[19]$} \\
\hline Escherichia coli NCTC 12923 & Reference strain & $\mathrm{n} / \mathrm{a}$ \\
\hline $\begin{array}{l}\text { Pseudomonas aeruginosa } \\
\text { SDM5 }\end{array}$ & Clinical isolate & $\mathrm{n} / \mathrm{a}$ \\
\hline Ps. aeruginosa NCTC 10662 & Reference strain & $\mathrm{n} / \mathrm{a}$ \\
\hline $\begin{array}{l}\text { Staphylococcus aureus } \mathrm{P} 10 \\
6 / 9\end{array}$ & Catheter biofilm & {$[13]$} \\
\hline
\end{tabular}

*Type strain

were also tested. Polydimethylsiloxanes of various molecular weight (Silanes \& Silicones Ltd., Manchester, United Kingdom), silica filler (hydrophobic Gelest filler; Silanes \& Silicones Ltd.) and hydrophilic Cabosil filler (Sigma-Aldrich) were mixed for at least $1 \mathrm{~h}$. The developed 'Base' was then used to prepare two component parts (parts A and B). Part A consisted of Base, platinum catalyst (Silanes \& Silicones Ltd.) and either the test antimicrobial or its control solvent. Part B consisted of Base, cross linker (Silanes \& Silicones Ltd.) and either antimicrobial agent or control solvent. Equal quantities of parts $A$ and $B$ were mixed and cured for $10-15 \mathrm{~min}$ at $90^{\circ} \mathrm{C}$ in an appropriate mould, resulting in a final concentration of $1 \%$ triclosan, $1 \%$ eugenol or $0.5 \%$ terpinen-4-ol solution in the cured silicone. Once cooled, the biomaterial was cut into $1-\mathrm{cm}^{2}$ squares and autoclaved. In addition, a triclosan containing silicone dip coat was also prepared using parts $A$ and $B$. Parts $A$ and $B$ were 
diluted separately at a ratio of $20 \%$ solid silicone formulation to $80 \% 1$ cst fluid (diluent) before equal amounts of diluted parts $A$ and $B$ were mixed resulting in a final concentration of $0.2 \%$ triclosan in the silicone dip coat. This silicone dip was used to coat all-silicone (100\%) Foley catheters (size 14 Ch; C. R. Bard, Inc., Crawley, United Kingdom) by immersion in the formulation for $5 \mathrm{~min}$, before air-drying for $12 \mathrm{~h}$.

Assessment of antimicrobial activity of developed silicone Bacteria maintained on CLED agar were sub-cultured in 10 $\mathrm{ml}$ of $\mathrm{MHB}$ and cultured for $16 \mathrm{~h}$ at $37^{\circ} \mathrm{C}$ with gentle rotation (100 rev/min). Test bacteria were spread-plated on ISO agar and incubated for $3.5 \mathrm{~h}$ at $37^{\circ} \mathrm{C}$. A silicone square $\left(1 \mathrm{~cm}^{2}\right)$ containing test antimicrobial or solvent control was placed in the centre of the agar. After incubation at $37^{\circ} \mathrm{C}$ for $16 \mathrm{~h}$, zones of growth inhibition were measured. Each antimicrobial material was tested in triplicate. Data from the zone of inhibition experiments were correlated and graphically depicted using GraphPad Prism ${ }^{\circledR}$ Software Version 4.00 (GraphPad Software Inc., La Jolla, USA).

To determine persistence of antimicrobial activity, silicone squares ( $10 \mathrm{~mm} \times 10 \mathrm{~mm} \times 5 \mathrm{~mm}$ containing $1 \%$ triclosan) were immersed in $1 \mathrm{~L}$ of artificial urine at $37^{\circ} \mathrm{C}$. At weekly intervals, specimens were removed and tested for antimicrobial activity against $P$. mirabilis NCTC 11938 using zone of inhibition testing. The artificial urine was replenished weekly for 11 weeks.

\section{Live/Dead staining of bacteria on antimicrobial bio- materials}

Proteus mirabilis NCTC 11938 was cultured for $4 \mathrm{~h}$ at $37^{\circ} \mathrm{C}$ in artificial urine. A portion of the culture was stained using LIVE/ DEAD ${ }^{\circledR}$ BacLight ${ }^{\mathrm{TM}}$ Bacterial Viability Kit (Molecular Probes Europe BV, The Netherlands) according to the manufacturer's instructions. A $10-\mu$ l volume of the stained bacteria was then deposited on the surface of the silicone and overlaid with a cover slip before being observed using time-lapse confocal microscopy over $24 \mathrm{~h}$.

\section{Prevention of urinary catheter encrustation by antimi-} crobial silicones

Cylinders ( $5 \mathrm{~mm}$ height) of solid silicone were constructed using cork-borers (Cole-Parmer Instrument Co. Ltd, United Kingdom). A single cylinder was located into the fluted part of the lumen of an all-silicone (100\%) Foley catheter prior to autoclaving. Test solid silicone contained a final concentration of $1 \%$ triclosan and control catheters contained solvent alone (2-propanol). Additional catheters were coated, intra- and extra-luminally, using liquid silicone formulation containing a final concentration of $0.2 \%$ triclosan and control catheters contained solvent (2-propanol) alone.

Test catheters were located within an in vitro bladder model (Figure 1; [21]) and the retention balloon inflated with $10 \mathrm{~mL}$ of sterile water. The catheter was connected to a drainage tube and bag in the standard way. The distance from the bottom

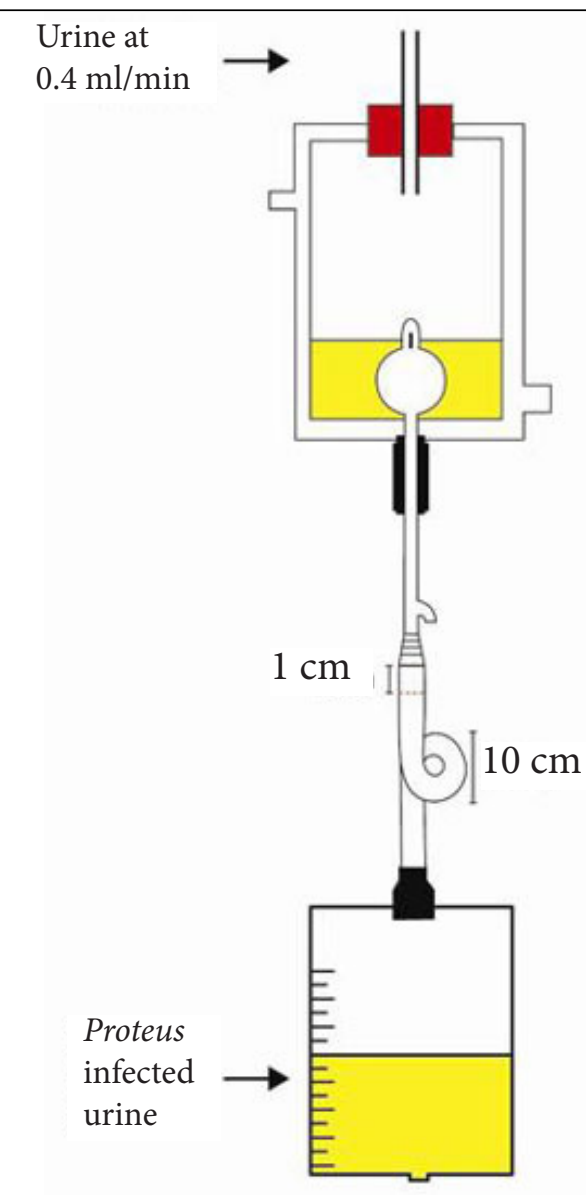

Figure 1. Schematic representation of the in vitro bladder model [21] used in the current study.

of the bladder chamber to the top of the drainage bag was $50 \mathrm{~cm}$ and a loop (outside radius $10 \mathrm{~cm}$ ) was introduced into the drainage system.

Artificial urine was added to the bladder chamber at $0.4 \mathrm{ml} /$ min via a peristaltic pump until it filled the bladder chamber to just below the catheter eyehole. Delivery of artificial urine to the bladder chamber was stopped and the drainage tube and bag completely emptied of artificial urine before inoculating the drainage bag (through the drainage tap) with 10 $\mathrm{mL}$ of a 4-h artificial urine culture of $P$. mirabilis NCTC 11938. Contamination events were performed four times per day and involved raising the drainage bag, to create a reverse flow of contaminated urine, to a defined level in the drainage tube and holding the contaminated urine at this level for $30 \mathrm{~s}$. Where catheters contained a solid silicone insert, the contamination level in the drainage tube was defined as the base of the inserted silicone material. Where the catheters were dip coated, the contamination level was defined at a $1 \mathrm{~cm}$ mark on the drainage tube, below the connection point of the drainage tube and the catheter (Figure 1). Supply of artificial urine was recommenced after each contamination event.

The models were run for a maximum of 7 days, or until the 
Jordan et al. Microbiology Discovery 2015,

catheters blocked. Catheters were defined as blocked when artificial urine began to collect in the bladder chamber, above the level of the catheter eyehole. Time taken for catheters to block was determined based on volume of urine removed from the drainage bags. Each experiment comprised of 3 'test' catheters and two 'control' catheters. Experiments were repeated on five separate occasions.

\section{Results}

\section{Antimicrobial activity of novel silicone materials}

Inhibition of growth based on agar diffusion was evident only with $1 \%$ triclosan-containing silicone, which was effective against 15 of the 18 test isolates (Providencia rettgeri SDM1, Pseudomonas aeruginosa SDM5 and Ps. aeruginosa NCTC 10662 were not susceptible; Figure 2). No antimicrobial activity was evident using eugenol or terpinen-4-ol incorporated into silicone, despite having previously demonstrated activity outside silicone against these bacterial strains [8]. Eugenol, when tested in its acetone diluent and not in silicone, retained its previously shown antibacterial effect, however, terpinen-4-ol, in the presence of acetone

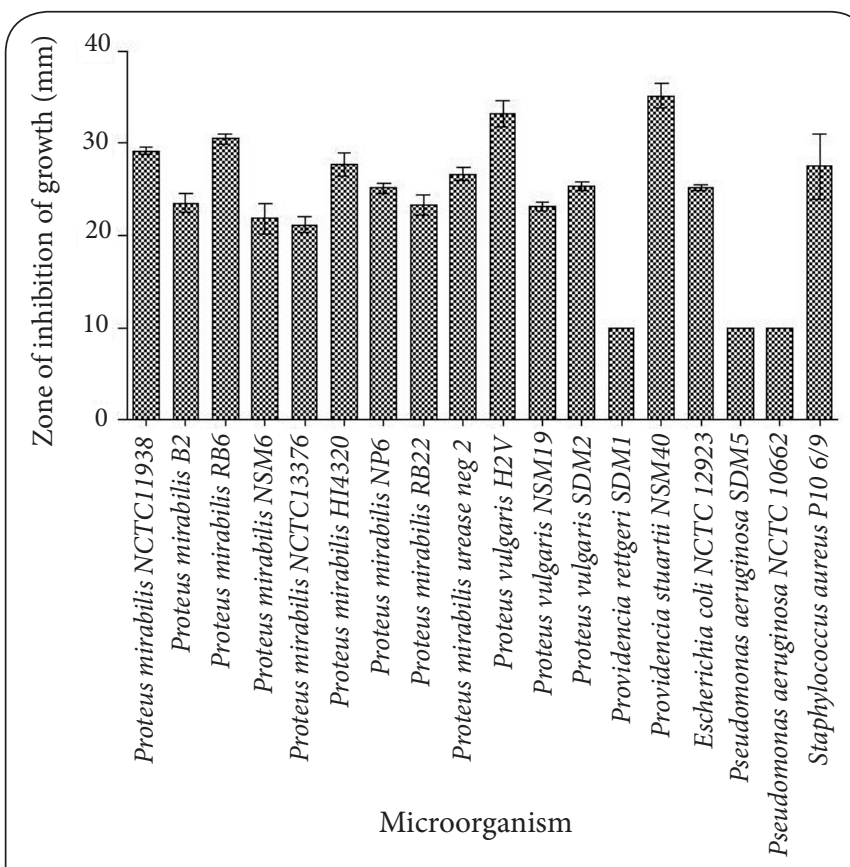

Figure 2. Antimicrobial activity of solid silicone containing triclosan against test bacterial strains.

Zones of inhibition of growth of selected bacterial strains involved in CA-UTI by a solid silicone formulation containing a final concentration of $1 \%$ triclosan. The zone of inhibition of growth of each isolate was measured in $\mathrm{mm}$ and the value shown above includes the $10 \mathrm{~mm}$ measurement of the silicone square. All isolates tested were susceptible to $1 \%$ triclosan in solid silicone formulation except Providencia rettgeri SDM1, Pseudomonas aeruginosa SDM5 and Ps. aeruginosa NCTC 10662. The graph represents the Mean and Standard Error of the Mean from duplicate readings taken when each antimicrobial material was tested in triplicate. solvent, lost its antibacterial activity (results not shown).

Live/dead staining of P. mirabilis NCTC 11938 on antimicrobial silicones was undertaken to assess whether antimicrobial effects were associated with the silicone surface only, as previous zones of inhibition experiments would have required release of the agent into the agar. In these studies, the time to kill $>95 \%$ of $P$. mirabilis NCTC 11938 deposited on the antimicrobial silicones was assessed in 24-h time course experiments. After 12 min, $>95 \%$ of $P$. mirabilis NCTC 11938 were killed on silicone containing $1 \%$ triclosan. Conversely, after $24 \mathrm{~h},>95 \%$ of $P$. mirabilis NCTC 11938 remained alive on eugenol- and terpinen-4-ol-containing silicone (Figure 3 ).

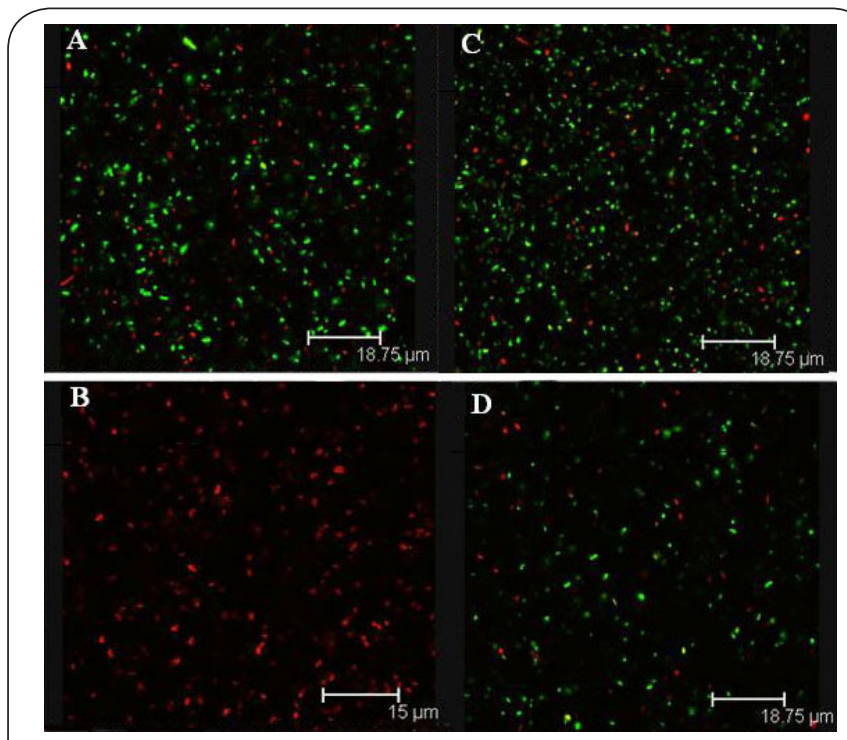

Figure 3. Live/Dead ${ }^{\circledR}$ staining of Proteus mirabilis NCTC 11938 after $24 \mathrm{~h}$ exposure to various solid silicone formulations.

Micrographs of Live/Dead stained Proteus mirabilis NCTC 11938 following 24-h exposure to solid silicone formulations A: control silicone containing solvent alone, B: triclosancontaining silicone, $\mathbf{C}$ : eugenol-containing silicone, D: terpinen4-ol-containing silicone. Live bacteria stain green and dead bacteria stain red. Over 95\% of Live/Dead stained P. mirabilis NCTC 11938 were alive following 24-h exposure to solid silicone formulation containing solvent alone (A), eugenolcontaining silicone (1\%) (C) and terpinen-4-ol-containing silicone (0.5\%) (D). Conversely, all P. mirabilis NCTC 11938 were dead following 24-h exposure to solid silicone formulation containing $1 \%$ triclosan (B).

As catheters can remain in place for up to 11 weeks, persistence of antimicrobial activity of solid silicone containing $1 \%$ triclosan was determined by immersing samples $(10 \mathrm{~mm} \times 10 \mathrm{~mm} \times 5$ $\mathrm{mm}$ squares) in artificial urine, which was replaced at weekly intervals. The antimicrobial effect of the triclosan containing silicone was retained over this period, despite a gradual reduction in the size of the zone of inhibition of growth of P. mirabilis NCTC 11834 from week 0 ( $29 \mathrm{~mm}$ zone including $10 \mathrm{~mm}$ silicone square) to week 11 (15 $\mathrm{mm}$ zone including 
Jordan et al. Microbiology Discovery 2015,

$10 \mathrm{~mm}$ silicone square) (Figure 4).

\section{Prevention of urinary catheter encrustation by triclosan containing silicone}

Where a solid triclosan silicone insert was used, out of 8 test catheters, only one showed delayed encrustation compared

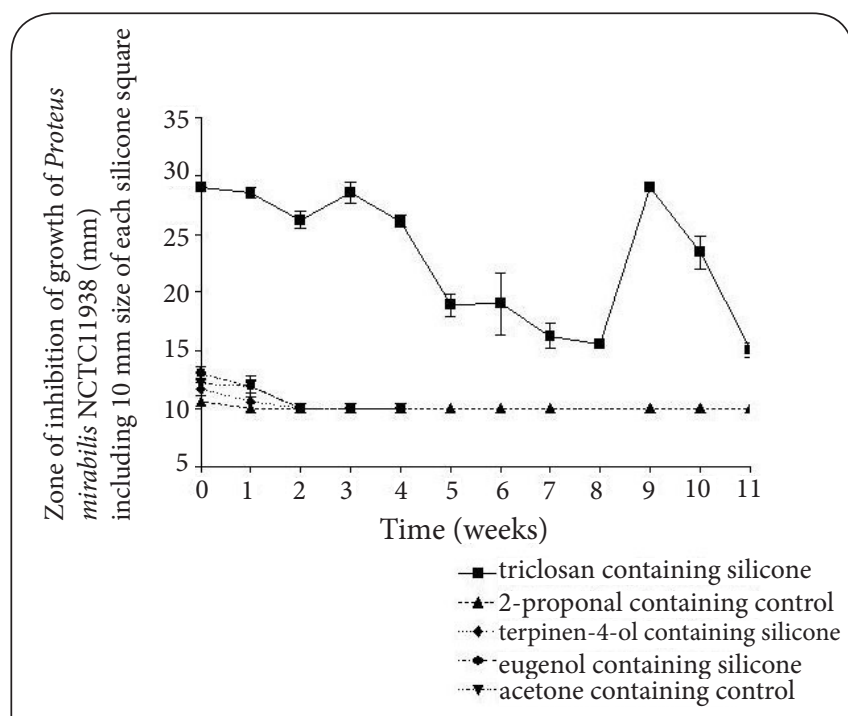

Figure 4. Antimicrobial activity of various solid silicone formulations against Proteus mirabilis NCTC11938 over a period of 11 weeks.

Three solid silicone squares $(10 \mathrm{~mm} \times 10 \mathrm{~mm} \times 5 \mathrm{~mm})$ of each silicone formulation were tested for antimicrobial activity at weekly intervals and results were recorded in duplicate for each solid silicone square. The diameter of the zone of inhibition of growth of Proteus mirabilis NCTC 11938 was measured in $\mathrm{mm}$ and included the width of the silicone square $(10 \mathrm{~mm})$. A decrease in the zone of inhibition can be seen for each silicone formulation except for triclosan containing silicone formulation where the zone of inhibition increased at week 9 and week 10. Testing of eugenol containing silicone formulation, terpinen-4-ol containing silicone formulation and the acetone containing control were discontinued after week 4 due to no zone of inhibition being observed from week 2 onwards. to their controls and one test catheter did not block at all (data not shown). Importantly, however, using a triclosan containing liquid dip coat silicone formulation, a notable delay in time to blockage was evident compared with controls (dip coat containing solvent alone). In the case of 13 test catheters, 12 exhibited delayed encrustation compared to controls, and 8 of these did not block over the 7-day duration of the experiment (Table 2).

\section{Discussion}

CA-UTIs are a major problem throughout the world. A key factor in individuals who have long-term indwelling catheters is contamination and infection by the urinary pathogen, $P$. mirabilis. Proteus mirabilis is not only able to rapidly migrate along the material of catheter surfaces to contaminate the bladder, it also generates a highly potent urease enzyme. Urease metabolises urea to produce ammonia, which, in a hydrated environment produces hydroxyl ions leading to elevated urine $\mathrm{pH}$. The potential effect of alkaline urine is subsequent crystallisation of magnesium and calcium phosphates leading to encrustation and catheter blockage [5]. Catheter blockage is clinically important, as not only will the resulting bladder distension be painful for the patient, but a blocked catheter also increases the risk of serious clinical complications including septicaemia and pyelonephritis [3].

Management of urinary catheter encrustation is difficult, and occurrence is both unpredictable and extremely hard to prevent with existing strategies [6]. Most often, the approach used is catheter replacement once blockage has occurred [22]. Unfortunately, such treatment is often unsuccessful with frequent recurrence of blockage evident [23]. Prophylactic antibiotic use to prevent recurrence is not ideal due to the potential promotion of antibiotic resistance [24-26]. One possible approach is to employ catheter materials that incorporate an antimicrobial agent that is either gradually released to the surface to inhibit colonisation or is utilised as an external catheter coating.

Previously, we have demonstrated the effectiveness of several antimicrobial agents against urinary tract pathogens

Table 2. Time (h) to blockage of catheters with triclosan-containing silicone dip coat (test) or the relevant solvent (control).

\begin{tabular}{llllcc}
\hline Catheter type & $\begin{array}{l}\text { Results of } \\
\text { Experiment } \mathbf{1}\end{array}$ & $\begin{array}{l}\text { Results of } \\
\text { Experiment } 2\end{array}$ & $\begin{array}{l}\text { Results of } \\
\text { Experiment } \mathbf{3}\end{array}$ & $\begin{array}{l}\text { Results of } \\
\text { Experiment 4 }\end{array}$ & $\begin{array}{l}\text { Results of } \\
\text { Experiment 5 }\end{array}$ \\
\hline Test & 150 & 132 & $>168$ & 160 & 140 \\
Test & 156 & $>168$ & $>168$ & $>168$ & $>168$ \\
Test & No model & No model & $>168$ & $>168$ & $>168$ \\
Control & 108 & 138 & 105 & 59 & 112 \\
Control & No model & No model & 97 & 87 & 95 \\
\hline
\end{tabular}

Five separate experiments containing 5 catheter models each were conducted to determine the time, in hours, to blockage of catheters dip-coated in liquid silicone formulation containing either triclosan (at a final concentration of $0.2 \%$ ) (test), or solvent alone (control). In experiment 1 and 2, results for only three catheter models were recorded due to leakage of two of the bladder models meaning time to blockage could not be accurately determined. Results indicating $>168 \mathrm{~h}$, define dip-coated catheters that did not block for the duration for the experiment. 
Jordan et al. Microbiology Discovery 2015,

http://www.hoajonline.com/journals/pdf/2052-6180-3-1.pdf

doi: $10.7243 / 2052-6180-3-1$

including P. mirabilis. These agents included natural compounds from plant extracts (tea tree oil, terpinen-4-ol, cineole, and eugenol [8]) and the widely used antimicrobial, triclosan [10]. Following this previous research, the aim of this study was to develop an antimicrobial insert or a coating that would theoretically prevent catheter encrustation caused by $P$. mirabilis infection.

Results showed that whilst several plant-derived antimicrobial agents had demonstrated previous in vitro activity against selected bacterial isolates [8], their incorporation into silicone or solvent, negated antimicrobial effects. Significantly, however, antimicrobial activity of triclosan was retained when incorporated into silicone as previous demonstrated $[\mathbf{2 7}, \mathbf{2 8}]$. Not only did this material show antibacterial activity using agar diffusion and Live/Dead assays, but there was also longterm (up to 11 weeks) persistence of antimicrobial activity.

It was initially envisaged that by incorporating a cylindrical section of this material into an existing Foley catheter, prevention of catheter encrustation by P. mirabilis (introduced below the point of material insertion) would follow. Unfortunately, this was not evident and may have been due to the design of the 'antimicrobial block' or to urinary flow over the surface of the cylinder allowing P. mirabilis to bypass the intended antimicrobial block. Significantly, however, use of triclosan within a dip coat silicone formulation resulted in a noticeable delay in catheter encrustation compared with controls. Indeed, over the 7-day period of running the in vitro bladder model, out of 13 repeated experiments delayed encrustation occurred in all but one occasion compared to controls. Furthermore, on 8 occasions there was no catheter blockage detected in any of the treated catheters over the duration of the experiment.

\section{Conclusion}

Use of such a dip coat has a number of advantages. Theoretically, it would be applicable to all commercially available silicone catheters without the need for modification in catheter design and application to the inner and outer luminal surfaces would provide potential protection against both routes of bladder contamination. Further studies with the triclosan silicone formulation are still warranted, including those that investigate potential host cell toxicity and long-term benefits following its application to indwelling urinary catheters in clinical settings.

\section{Competing interests}

The authors declare that they have no competing interests.

\section{Authors' contributions}

\begin{tabular}{|l|c|c|c|c|c|}
\hline Authors' contributions & RPCJ & SM & MGW & DJS & DWW \\
\hline Research concept and design & -- & -- & $\checkmark$ & $\checkmark$ & $\checkmark$ \\
\hline Collection and/or assembly of data & $\checkmark$ & $\checkmark$ & -- & -- & -- \\
\hline Data analysis and interpretation & $\checkmark$ & -- & -- & -- & -- \\
\hline Writing the article & $\checkmark$ & -- & -- & -- & -- \\
\hline Critical revision of the article & -- & $\checkmark$ & -- & -- & $\checkmark$ \\
\hline Final approval of article & -- & -- & -- & $\checkmark$ & $\checkmark$ \\
\hline Statistical analysis & $\checkmark$ & -- & -- & -- & -- \\
\hline
\end{tabular}

\section{Acknowledgement}

The authors would like to thank MBI Wales, Great Bear Health Care, and the Wales Assembly Government for their support of this research.

\section{Publication history}

Editor: António Pedro Fonseca, University of Porto, Portugal. EIC: Todd R. Callaway, Food and Feed Safety Research Unit, USA. Received: 17-Nov-2014 Final Revised: 21-Dec-2014

Accepted: 12-Jan-2015 Published: 22-Jan-2015

\section{References}

1. Weber DJ, Sickbert-Bennett EE, Gould CV, Brown VM, Huslage K and Rutala WA. Incidence of catheter-associated and non-catheterassociated urinary tract infections in a healthcare system. Infect Control Hosp Epidemiol. 2011; 32:822-3. I Article I PubMed

2. Feneley RC, Kunin CM and Stickler DJ. An indwelling urinary catheter for the 21st century. BJU Int. 2012; 109:1746-9. | Article I PubMed

3. Stickler DJ and Zimakoff J. Complications of urinary tract infections associated with devices used for long-term bladder management. J Hosp Infect. 1994; 28:177-94. | Article | PubMed

4. Stickler D, Ganderton L, King J, Nettleton J and Winters C. Proteus mirabilis biofilms and the encrustation of urethral catheters. Urol Res. 1993; 21:407-11. | Article | PubMed

5. Morris NS, Stickler DJ and McLean RJ. The development of bacterial biofilms on indwelling urethral catheters. World J Urol. 1999; 17:345-50. | Article | PubMed

6. Trautner BW and Darouiche RO. Role of biofilm in catheter-associated urinary tract infection. Am J Infect Control. 2004; 32:177-83. | Article | PubMed Abstract | PubMed Full Text

7. Nikolić M, Marković T, Marković D, Perić T, Glamočlija J, Stojković D and Soković M. Screening of antimicrobial and antioxidant activity of commercial Melaleuca alternifolia(tea tree) essential oils. J Med Plants Res. 2012; 6:3852-3858. I Pdf

8. Malic S, Jordan RP, Waters MG, Stickler DJ and Williams DW. Biocide activity against urinary catheter pathogens. Antimicrob Agents Chemother. 2014; 58:1192-4. I Article I PubMed Abstract I PubMed Full $\underline{\text { Text }}$

9. Pirard C, Sagot C, Deville M, Dubois N and Charlier C. Urinary levels of bisphenol A, triclosan and 4-nonylphenol in a general Belgian population. Environ Int. 2012; 48:78-83. I Article I PubMed

10. Williams GJ and Stickler DJ. Effect of triclosan on the formation of crystalline biofilms by mixed communities of urinary tract pathogens on urinary catheters. J Med Microbiol. 2008; 57:1135-40. | Article | PubMed

11. Hauser G. Uber Fiiulnisbakterien. Leipzig. 1885; 1-73. I Pdf

12. Stickler DJ, Lear JC, Morris NS, Macleod SM, Downer A, Cadd DH and Feast WJ. Observations on the adherence of Proteus mirabilis onto polymer surfaces. J Appl Microbiol. 2006; 100:1028-33. | Article | PubMed

13. Broomfield RJ, Morgan SD, Khan A and Stickler DJ. Crystalline bacterial biofilm formation on urinary catheters by urease-producing urinary tract pathogens: a simple method of control. J Med Microbiol. 2009; 58:1367-75. | Article | PubMed

14. Stickler DJ and Morgan SD. Modulation of crystalline Proteus mirabilis biofilm development on urinary catheters. J Med Microbiol. 2006; 55:489-94. | Article | PubMed

15. Jones BD and Mobley HL. Genetic and biochemical diversity of ureases of Proteus, Providencia, and Morganella species isolated from urinary tract infection. Infect Immun. 1987; 55:2198-203. | Article I PubMed Abstract | PubMed Full Text

16. Warren JW, Tenney JH, Hoopes JM, Muncie HL and Anthony WC. A prospective microbiologic study of bacteriuria in patients with chronic indwelling urethral catheters. J Infect Dis. 1982; 146:719-23. | Article | PubMed 
Jordan et al. Microbiology Discovery 2015,

http://www.hoajonline.com/journals/pdf/2052-6180-3-1.pdf

17. Sabbuba NA, Mahenthiralingam E and Stickler DJ. Molecular epidemiology of Proteus mirabilis infections of the catheterized urinary tract. J Clin Microbiol. 2003; 41:4961-5. | Article I PubMed Abstract | PubMed Full Text

18. Sabbuba N, Hughes $G$ and Stickler DJ. The migration of Proteus mirabilis and other urinary tract pathogens over Foley catheters. BJU Int. 2002; 89:55-60. | Article | PubMed

19. Jones GL, Muller CT, O'Reilly M and Stickler DJ. Effect of triclosan on the development of bacterial biofilms by urinary tract pathogens on urinary catheters. J Antimicrob Chemother. 2006; 57:266-72. | Article I PubMed

20. Griffith DP, Musher DM and Itin C. Urease. The primary cause of infection-induced urinary stones. Invest Urol. 1976; 13:346-50. | Article PubMed

21. Stickler DJ, Morris NS and Winters C. Simple physical model to study formation and physiology of biofilms on urethral catheters. Methods Enzymol. 1999; 310:494-501. | Article | PubMed

22. Stickler DJ. Clinical complications of urinary catheters caused by crystalline biofilms: something needs to be done. J Intern Med. 2014 276:120-9. | Article | PubMed

23. Mathur S, Suller MT, Stickler DJ and Feneley RC. Prospective study of individuals with long-term urinary catheters colonized with Proteus species. BJU Int. 2006; 97:121-8. I Article I PubMed

24. Hooton TM, Bradley SF, Cardenas DD, Colgan R, Geerlings SE, Rice JC, Saint S, Schaeffer AJ, Tambayh PA, Tenke P and Nicolle LE. Diagnosis, prevention, and treatment of catheter-associated urinary tract infection in adults: 2009 International Clinical Practice Guidelines from the Infectious Diseases Society of America. Clin Infect Dis. 2010; 50:625-63. | Article | PubMed

25. Jacobsen SM, Stickler DJ, Mobley HL and Shirtliff ME. Complicated catheter-associated urinary tract infections due to Escherichia coli and Proteus mirabilis. Clin Microbiol Rev. 2008; 21:26-59. I Article I PubMed Abstract I PubMed Full Text

26. Britt MR, Garibaldi RA, Miller WA, Hebertson RM and Burke JP. Antimicrobial prophylaxis for catheter-associated bacteriuria. Antimicrob Agents Chemother. 1977; 11:240-3. I Article I PubMed Abstract | PubMed Full Text

27. Gaonkar TA, Caraos $L$ and Modak S. Efficacy of a silicone urinary catheter impregnated with chlorhexidine and triclosan against colonization with Proteus mirabilis and other uropathogens. Infect Control Hosp Epidemiol. 2007; 28:596-8. | Article | PubMed

28. Kazmierska KA, Thompson R, Morris N, Long A and Ciach T. In vitro multicompartmental bladder model for assessing blockage of urinary catheters: effect of hydrogel coating on dynamics of Proteus mirabilis growth. Urology. 2010; 76:15-20. | Article | PubMed

\section{Citation:}

Jordan RPC, Malic S, Waters MG, Stickler DJ and Williams DW. Development of an antimicrobial urinary catheter to inhibit urinary catheter encrustation. Microbiol Discov. 2015; 3:1. http://dx.doi.org/10.7243/2052-6180-3-1 